\title{
Hearing Jeremiah's Confessions in Light of the Metaphor of the 'Silent' Sheep: Reflections through the African Lore
}

\author{
Madipoane Masenya (NgWan'A MPHAhlele) (University OF \\ SOUTH AFRICA)
}

\begin{abstract}
In varying African cultures, and dare one say, even in global cultures, normative masculinity is defined among others, by men's capacity not to cry. Expressing feelings such as helplessness, weakness, being overwhelmed, pain and trauma overtly, is not supposed to typify normative manhood. Yet the book of Jeremiah (cf. his confessions in particular), canonised as it is in the Christian Bible, reveals that overt male expression of feelings can actually be a conduit through which the prophetic word is conveyed to the prophet and through the prophet to his audiences. Complaints/laments seem to have unashamedly formed an integral part of the life and ministry of the prophet Jeremiah, the man (cf. 14:17; 15:18). The main question engaged with in this article is: Which reading may emerge if selected Sotho proverbs on specific masculinities are used as hermeneutical lenses through which to engage the confessions of Jeremiah?
\end{abstract}

KEYWORDS: confessions of Jeremiah, crying/tears, weeping, man/masculinity, Jer. 20:7-18; African/Northern Sotho context.

\section{A INTRODUCTION}

Monna ke nku, o llela teng (Sotho proverb) 1

A man is a sheep he cries inwardly;

Monna ke nku, mosadi ke pudi (Sotho proverb)2

A man is a sheep, a woman is a goat.

“...Let my eyes run down with tears night and day, and let them not cease, for the virgin daughter of my people has been broken with a great blow, with a very infected wound." (Jer 14:17 MEV)

* Submitted: 04/10/2018; peer-reviewed: 24/12/2018; accepted: 09/01/2019. Madipoane Masenya, “Hearing Jeremiah's Confessions in the Light of the Metaphor of the 'Silent' Sheep: Reflections Through the African Lore," 31 no. 3 (2018): 705-718. DOI: https://doi.org/10.17159/2312-3621/2018/v31n3a17.

1 Rakoma, JRD. Marema-ka-dika t⿳亠丷厂̆a Sesotho sa Leboa. (Pretoria: Van Schaik, 1971).

2 Rakoma, Marema-ka-dika, 1971. 
"Why is my pain perpetual and my wound incurable, which refuses to be healed?" (Jer 15:18 MEV)

In this article, two Sotho proverbs serve as hermeneutical lenses through which I interact with the material from the Jeremiah tradition, in particular, the material from the texts named as the confessions/complaints of Jeremiah. The bringing together of a theme such as "the weeping/tearful man" from an ancient context, so far removed from present day Bible readers' contexts, is made possible by the important role which the Christian scriptures continue to play in present day ecclesial contexts, including the ecclesial context of the Honoree, Professor Wilhelm J. Wessels. The words of Timothy Polk come to mind here: "However the text achieved its present shape, it is that shape that confronts the reader and is the primary determinant of meaning (as well as the primary witness to what the writers might have intended)."3

Thus, for many a present day Bible reader, what matters most is not so much questions of historical-critical concerns like whether the words contained in the confessions, could be linked to the prophet Jeremiah himself ${ }^{4}$ or whether the words did not come from the historical prophet, Jeremiah. ${ }^{5}$ The preceding

3 Timothy Polk. The Prophetic Persona: Jeremiah and the Language of Self (Sheffield: JSOT, 1984), 130. On the role of the Bible in the context present day Bible reading communities irrespective of the global context in which they are located, see also Madipoane Masenya (ngwana' Mphahlele) and Hulisani Ramatswana on the role of the Bible in the context of present-day Bible reading communities, "Anything New under the sun of Old Testament scholarship? African Qoheleths' review of OTE 19942010, Old Testament Essays25 (3), 598-637; 2012.

4 Gerhard von Rad, "The Confessions of Jeremiah," in A Prophet to the Nations: Essays in Jeremiah Studies, (eds. Leo G. Perdue and Brian W. Kovacs (Winona Lake, IN: Eisenbrauns, 1984), 339-347). REO White, The Indomitable Prophet: A Biographical Commentary on Jeremiah: The Man, the time, the Book, the Tasks (Grand Rapids: William B. Eerdmans), 1992); Kathleen M. O'Connor. The Confessions of Jeremiah; Their interpretation and role in Chapters 1-25, SBL Dissertation Series (Atlanta, GA: Scholars Press), 1988; Kathleen M. O'Connor. Jeremiah, Pain and Promise, (Minneapolis: Fortress), 2011); Kathleen M. O'Connor, "Jeremiah", in Women's Bible Commentary, Twentieth Anniversary Edition, (eds. Carol A. Newsom, Sharon H. Ringe and Jacqueline E. Lapsley (Louisville, KY: Westminster John Knox, 2012), 267-277; Walter Brueggemann, To pluck up, to tear down A Commentary of the Book of Jeremiah1-25 (Grand Rapids, CO: WM. B. Eerdmans; Edinburgh: The Handsel), 1988; Lundbom, Jack R. Jeremiah 1-20: A New Translation with Introduction and Commentary, AB 21 A (New York: Doubleday, 1999).

5 Robert P. Carroll. Jeremiah: Volume 1 (Sheffield: Sheffield Phoenix), 2006 is one of the scholars who is sceptical about efforts to link the material in the book of Jeremiah with the prophet himself. Argues Carroll, "Anonymity or fictive representation is the mark of these works and the laments in the Jeremiah tradition probably should be seen in similar terms." Robert P. Carroll. Jeremiah: Volume 1 (Sheffield: Sheffield Phoenix, 2006), 278; R.P. Carroll, Jeremiah (Sheffield: Sheffield Academic, 1989) 
questions focus on whether the words from Jeremiah's poems, like many of the psalms of lament, were uttered in a cultic setting or not ${ }^{6}$. Important as the preceding questions are, especially to biblical scholars, they are not a priority to many an (African) Bible reader. What counts most to the preceding readers (cf. also the underlying assumptions which underlies the present essay), are the confessions of Jeremiah as they are reflected in the Bible in its present canonical shape. Although the confessions are classified differently by various scholars, the following classification appears to be the commonly accepted one: Jer. 11:18$12: 6 ; 15: 10-21 ; 17: 12-13 ; 14-18 ; 18: 19-23 ; 20: 7-18 .^{7}$

The two proverbs which will serve as the reading glasses through which the life of Jeremiah as a complaining, crying man is read, are as follows, first, monna ke nku, o llela teng translated, "a man is a sheep, he cries inwardly"; and second, monna ke nku, mosadi ke pudi translated as, "a man is a sheep, a woman is a goat". From the preceding proverbs, it is clear that according to the Sotho mentality, of the two domestic animals which formed/form part and parcel of various African households, that is a sheep and a goat, a sheep appears to have been more valued and celebrated than a goat. On the one hand, a sheep is linked with forbearance, for example, even if a sheep hurts, one will hardly notice that it does, because it is claimed that it "cries inwardly." A sheep is not loud, it is thus associated with silence. A sheep is also linked with decency. On the other hand, a goat is linked with being loud as it expresses its emotions freely and anywhere. As a goat is not capable of being forbearing, or remaining calm while under pressure, it is associated with cowardice to some extent. Ironically, there is a Sotho proverb that lauds a human being's capacity to be a coward. ${ }^{8}$ If it was human, a goat would most probably not be trusted to keep other people's secrets.

As can be expected in a patriarchal culture, a culture where the male is the norm, it comes as no surprise that a more valued animal (cf. sheep in the present case) would be linked to a man while a less valued one, one claimed to possess visible "weaknesses" (cf. a goat) would be linked to a woman hence the proverb, monna ke nku, mosadi ke pudi (a man is a sheep, a woman is a goat). A woman is loud, she can thus not keep secrets, the latter, is as a matter of fact, the tenor of the proverb which compares her with a goat (Rakoma1971). As she can release tears effortlessly, she cannot display the "decency" of a sheep (read: man) which cries inwardly ${ }^{9}$. As a loud person, a woman, unlike a sheep, does not have

6 See O'Connor, The Confessions, 1988.

7 There is a difference of opinion as to whether the last episode, the "curse poem" (Jer. 20:14-18), was originally part of the last confession or not. In this essay, the curse poem is treated as part of the confession (cf. the argument on the present canonical shape of the confessions mentioned earlier on).

${ }^{8}$ Ga bo lefšega ga go lliwe, translated as "a household of a coward (whether male or female) never gets to experience mourning."

9 Says O'Connor, "Jeremianic themes of weeping and lamentation call upon common human experience, but in some cultures, it is women who are particularly 
the capacity to cry inwardly. While a man should not be a goat (read: a woman), a true man, like a sheep, does not cry overtly, and hence, monna ke nku, o llela teng translated, "a man is a sheep, he cries inwardly." Normative masculinity in African cultures, and dare one say, also in global cultures, is revealed in among others, by men's capacity not to cry.

Argues Ezra Chitando, "The conventional wisdom is that men do not cry. Men themselves have been socialized to suppress their emotions, and crying is regarded as a sign of weakness. Hegemonic masculinities on the other hand place emphasis on strength and emotionlessness."10 Expressing one's feelings of helplessness, weakness, being overwhelmed, rage, pain and trauma overtly, is not supposed to typify normative manhood. Commenting on the context of the character Temba in the publication, "When a Man Cries", Chitando argues: "In this scheme, real men are made of steel; they betray no emotions at all."11

However, even a cursory glimpse at the life of the prophet Jeremiah as revealed in his confessions, depicts a scenario contradicting the one portrayed by the preceding Northern Sotho proverbs.

The main question engaged with in this article is thus: Which reading may emerge if selected Sotho proverbs on specific masculinities are used as hermeneutical lenses through which to engage the confessions of Jeremiah?

In the following paragraphs, we take a brief look at Jeremiah, the male human being as it is revealed in selected texts from some of his confessions.

\section{B JEREMIAH AND REAL MANHOOD?}

Coming from a culture which seems to prescribe that tears, weeping, being loud and complaining, could never typify real/ideal masculinity ${ }^{12}$, makes one

familiar with weeping and grief- grief for their children, for their loved ones, for themselves, for the world. Jeremiah's weeping may help women recognize and express their own unnamed grief, and perhaps it may help them place their suffering before God, not a God who threatens and punishes, but a weeping God who takes up women's pain and weeps with them."(Italics: Authors) Kathleen M. O'Connor, "Jeremiah" in Women's Bible commentary, Twentieth Anniversary Edition (eds. Carol Newsom, Sharon H. Ringe and Jacqueline and Lapsley (Louisville: Westminster John Knox, 2012), 275.

10 Ezra Chitando, "Redemptive Masculinities, HIV, and Religion in Siphiwo Mahala's When a Man Cries" Pages 249-266 in Redemptive Masculinities: Men, HIV and Religion. Edited by Ezra Chitando and Sophie Chirongoma. (Geneva: WCC, 2012), 258.

11 Chitando, "When a Man Cries", 250.

12 Within such a culture, argues Musa Dube ("Culture, Gender and HIV/AIDS: Understanding and Acting on the Issues" in HIV/AIDS and the Curriculum: Methods of Integrating HIV/AIDS in Theological Programmes. Edited by Musa W. Dube 
fascinated by a reading of the laments/complaints/confessions of Jeremiah, the male human being.

Although there are indications that even in the socio-historical context of the prophet Jeremiah (cf. Jer.9:17-19), there seems to have been an understanding that lamentation/ weeping and tears were (biologically/culturally) a feminine thing ${ }^{13}$, it is interesting to note that a male human being like Jeremiah, could easily shed his tears and express his feelings of pain, fear, frustration and anger among others, effortlessly and unashamedly. In his confessions, Jeremiah finds it easy to vent out his anger, not only at his friends or at the religious establishment of his time, or the day on which he was born, or even at the messenger who brought the news of his arrival on Earth. The prophet also freely vents out his anger, frustrations and even accusations at Yahweh, the God who had called him to the daunting prophetic task. The words of White come to mind here, "Prophet and psalmist alike teach us very firmly that the right way to deal with doubt and protest within the soul is to carry them straight to God and never let them carry us away from him. God is his own interpreter, and he will make things plain. ${ }^{14}$

\section{INTERROGATING MALE “GOAT-LIKE” BEHAVIOUR?}

The confessions provide language for disaster victims to complain about all that is unendurable. Attacked, defenceless, and mortally threatened, Jeremiah is " a lamb led to the slaughter," his enemies try to "cut off his life from the land of the living, to destroy the tree with its fruit" (11:19), even his family and kinsfolk turn against him $\left(11: 21-23 ; 12: 6\right.$, italics: author's). ${ }^{15}$

In the very first confession (cf. Jer. 11:18-12:6), the metaphor of a human being as sheep/lamb features:

(Geneva: World Council of Churches, 2003) "a man will never cry unless his heart would break. "So, men are socially constructed not to express their feelings of fear or pain...they are to show no emotion." (2003:86-87) as quoted by Chitando, "When $a$ Man Cries", Ibid, 263.

13 The words of O'Connor are on target here, "The theme of weeping is notable in the book, though within the tradition of lamentation, lacks the protest in the lament. The weeping of the mourning women, Jeremiah, the earth and the forlorn Rachel signifies the imminence and inevitability of the destruction as well as the recognition of deep, irrevocable loss; the tears of God though, ruptured theological language, "The book's lead character breaks from his role as dominating, proud male, cruel architect of war, and for a brief poetic interlude embodies and participated in the pain of the people." Kathleen M. O'Connor. "The tears of God and Divine character in Jeremiah 2-9" in Troubling Jeremiah, (eds. A.R. Pete Diamond, Kathleen M. O'Connor and Louis Stulman (Sheffield: Sheffield, 1999), 401.

14 White, the Indomitable Prophet, 161.

15 O'Connor, Jeremiah, Pain and Promise, 88. 
But I was like a gentle lamb let to the slaughter, And I did not know it was

Against me,

That they devised schemes... (Jer. 11:19)

Noteworthy is the vulnerability with which Jeremiah portrays his precarious situation. He is like a baby sheep, that is, a lamb ${ }^{16}$ which, although small and fragile, is led to the slaughter. "He compares himself to a docile lamb which naively follows the person who is taking it to be slaughtered-a moving image!"17 The notion of a sheep (lamb) which is celebrated (cf. the mentality embedded in the preceding Sotho proverbs) is depicted by the lamb's innocence in the present textual context. The vulnerability of a gentle lamb serves also to contrast the "lamb" (read: vulnerable Jeremiah) with the cruelty of the enemies who torture an "innocent" victim. In that way, the "powerlessness"/ "weakness" of the lamb stands in tension with the power of Jeremiah's enemies (most of whom were probably men). According to the mentality embedded in the Sotho proverbs, although Jeremiah portrays himself as being like an innocent lamb which is led to the slaughter, given his tone in this confession/complaint, Jeremiah is in fact displaying "goat-like" qualities by being loud. His confessions are as a matter of fact his complaints. In his loudness, Jeremiah acts like a goat and thus seems to lack real men's capacity to be calm and collected even in the midst of harsh opposition. As he lives out his emotions of fear and anxiety about those who devise evil plots against him (Jer.11:18), Jeremiah provides his modern day readers, a window into our human capacity to be afraid, to doubt and to complain. Noteworthy is that the preceding human tendencies, despite how we were socialised, cuts across all humans irrespective of their gender and sexual orientation. Jeremiah, the man, is just as human as all other Judean people of his time. Wilhelm Wessels could thus rightly argue,

The fact that he was a prophet did not detract from his humanity or elevate him above other human beings. He had to deal with all the conflicting emotions others had to deal with-such as feelings of betrayal and of being deprived of the protection of YHWH. He had to cope with strong feelings similar to those of many people in Judah, like wanting to detach himself from the covenant God who deals so harshly with his people. And yet he has decided to remain loyal to YHWH and surrender to the power of YHWH's word. ${ }^{18}$

16 The prophet's helplessness expressed through the lamb metaphor, becomes pronounced when we consider with Wakter Baumgartner that a lamb was one of the Israelite animals which was used for sacrifices. Jeremiah's poems of lament, translated by David E. Orton (Sheffield: Sheffield Academic, 1988) 43.

17 Baumgartner, Jeremiah's poems, 43.

18 Wilhelm Wessels, "My Word is Like Fire": The Consuming Power of YHWH's Word, OTE 24/2 (2011), 502. 
The complaining "vulnerable", "cowardly" "fearful" messenger fails to appeal to the empathy of the One who sent him. As if being commanded to "(hu)man up", Yahweh responds:

If you have raced with

Foot-runners and they have wearied you,

How will you compete with horses?

And if in a safe land you fall down,

How will you fare in the thickets of the Jordan (12:5, NRSV)

The messenger was already alerted in this call to prophetic ministry about the message of judgement he was to proclaim to his people even as he was also instructed to be firm: "But you, gird up your loin; stand up and tell them everything that I command you. Do not break down before them.'(Jer.1:17)

A sense of self-pity and perhaps even self-hate is notable at the beginning of the second confession (Jer. 15:10-21). An intense sense of self-pity persuades the prophet to focus on himself and himself alone; the latter focus is done even at the expense of the intense labour pains suffered by his mother when he was born. His suffering makes Jeremiah to wish that he should never have seen the light of the day. He has become an object of a curse by all in the land. As a loud goat, Jeremiah does not shy away from complaining about his continuing pain and the wound that refuses to get healed (Jer.15:18). If Jeremiah was the proverbial sheep that cries inwardly, present day readers of his confessions/prayers would not have gotten a glimpse about his continuous experience of the pain (physical/emotional/mental) as well as the wound that refuses to heal. The reader would thus have been equally deprived of the kind of stubborn faith that the prophet had in Yahweh, the faith that enables him to cling to his God despite the intensity and the duration of his adversity.

In the third, confession, Jer. 17:12-13; 14-18, Jeremiah's display of his search for healing and/or acknowledgement of his ill health (sickness) and his search for salvation are other pointers to his humanness and/or mortality. As O'Connor rightly points out, "And like his people, Jeremiah too needs to be saved and healed $(17: 14-16 ; 18: 20 \mathrm{~b})^{19}$.

Jeremiah has a need, as any other mortal being, he can get sick, his physical body can fail him and he can thus cry out to God to seek the healing of his body. Acknowledging that he is lost, vulnerable and in trouble, he turns to God to seek his redemption/salvation (17:14). Unlike a sheep that is supposed to suffer in silence, even in this confession, the prophet reveals the "fear" or anxiety that comes from the opposition he experiences from his enemies. In a way, Jeremiah is calling God to responsibility regarding the fulfilment of his word,

19 O’Connor, Jeremiah, Pain and Promise, 88 
that despite the promises of the impending judgment, the fulfilment of the promises appear to linger so long.

Jeremiah persists in his being loud (cf. goat-like behaviour) in the fourth confession (Jer 18:18-23). His anxiety is caused by the murderous plots from his adversaries. He refuses to keep quiet. He cries out/complains to God about the fact that the enemies have dug a pit for him even though he had done no evil. Threats from his adversaries make him restless, he cannot afford to be an inward crying sheep. The evil they plan for him (cf. digging a pit) stands in tension to the good he had done for them (interceding that God's wrath would not come upon them). The compassion which he previously had towards them as his own beloved people who were about to face Yahweh's wrath ${ }^{20}$ is now replaced by his rage and spirit of vengeance. His rage against the enemies makes him pray for a communal vengeance upon the enemies; their wives and children must also suffer the consequences of the evil plot of the men in their lives. He pleads with Yahweh to deal with them in his anger (18:23).

As the fifth confession, Jer. 20:7-18, begins, the powerlessness/ weakness of Jeremiah, the mortal hu(man) is contrasted with that of the deity, Yahweh. Yahweh has enticed him and overpowered him (20:7). Argues Carroll, "The poem in vv.7-10 is a familiar cry of outrage and suffering directed at the deity because of the persecuted state in which the speaker finds himself."21

Jeremiah becomes the object of Yahweh's negative actions upon him, the latter actions, had become the prophet's lot despite the fact that he had remained faithful to his call as a prophet. Jeremiah's display of restlessness and anxiety about the threats that were mouthed by his enemies (including his friends) continue to surface even in the present complaint/confession (Jer.20:10). The strong opposition to the judgemental message that he prophesies, the threats as well as the persecutions which he had to endure, seem to have persuaded him at times to want to give up on the prophetic ministry:

But if I say, "I will not make mention of Him nor speak any more in His name," then His word was in my heart as a burning fire shut up in my bones; and I was weary of forbearing it, and I could not endure it (Jer. 20:9, italics author's).

Jeremiah's apparent incapacity to bear Yahweh's words in perseverance and silence like it is expected from a typical man, may not be taken kindly to, in contexts where men are expected to cry inwardly. The complaint depicted in the

20 Says von Rad on Jeremiah's intercessory role: “.... as intercessor, Jeremiah not only endures the suffering that men ( sic) have caused him, but also he has taken upon himself all of their misery; they are present in his deepest struggles, and with these men (sic) for whom he suffers, Jeremiah must die in the sight of God, yes he dies many deaths with them until his own final, physical death." Von Rad, the Confessions, 37.

21 Carroll, “Jeremiah”, 398 
preceding verse, may be viewed as both cowardice and a lack of faith on the part of a man in whom Yahweh had such confidence as to entrust him with the kind of heavy message that he carried. As the God who had assured Jeremiah of his presence and protection, right at the moment of his call, one who had made him "...a fortified city, an iron pillar, and a bronze wall, against the whole landagainst the kings of Judah, its princes, its priests, and the people of the land..." (Jer.1:18), Jeremiah had no need to complain or to mouth words of vengeance towards his people, it may be argued.

In the preceding paragraphs, the reader has hopefully caught a glimpse of the fact that Jeremiah deviated from the acceptable notions of $\mathrm{manhood} / \mathrm{masculinity,} \mathrm{at} \mathrm{least} \mathrm{from} \mathrm{our} \mathrm{present} \mathrm{reading} \mathrm{lenses,} \mathrm{that} \mathrm{is} \mathrm{the} \mathrm{Sotho}$ proverbs. A male human being can also freely express his emotions of doubt, fear and hurt freely. Even within Jeremiah's context, it would appear that Jeremiah was an exception among men who could not express their emotions/tears unashamedly. What is curious at this point is the location at which a weeping man could have uttered the confessions. What is the space in which such frank conversations between the prophet, a human being and the deity may have occurred? May such bold, outrageous utterances, ones revealing the vulnerability of a male human being, have occurred in private or in public? Identifying the preceding space, in my view, may assist present day Bible readers in throwing some light on Jeremiah's spirituality, that is, the prophet's relationship with the deity.

\section{THE SPACE OF JEREMIAH'S COMPLAINTS: A MIRROR INTO HIS SPIRITUALITY}

The complicated history behind the literary composition of the book of Jeremiah is attested to by many scholars. It thus becomes difficult to pinpoint the original setting in which Jeremiah's laments/prayers/confessions could have been uttered. However, from their present content and form, it becomes clear to present day Bible readers that they were uttered in a "sacred" space. Whether that space was a public one (possibly not the temple given the prophet's indictment on the royal-temple ideology among others) ${ }^{22}$ or private one (in the midst of the closer circle of his disciples) $)^{23}$, or a very private solitary space, what is clear though, is that the confessions portray an open and honest conversation between the prophet and his God. They might have been uttered originally in a private space where the prophet could freely display his real self in the presence of Yahweh, the one whom he seems to have known so closely. Jeremiah's ability

22 Due to Jeremiah's rejection by most of the religious establishment, the temple would not be a probable setting within which the confessions were uttered, instead, as O'Connor argues, "The more likely arena for the recitation of the confessions would have been among those who supported him but who may have been losing faith in him due to his apparent failure" (See O'Connor, The Confessions, 95).

23 See O'Connor, The Confessions, 95 
to express all sorts of feelings, even those which are usually linked to female human beings such as: fear/cowardice, weakness (of body and soul), brokenness, being overwhelmed, complaining/crying and weeping among others, in my view, reveals his comfort in being a real human being, one who refused to be pressurized by the patriarchal masculinist views of the time. "Thus, now - and in Jeremiah this is something new - the prophet not only becomes a witness of God through the strength of his charisma, but also in his humanity; but not as the one who triumphs over the sins of mankind (sic), not as one overcoming, but as a messenger of God to mankind (sic) breaking under the strain. Hence Jeremiah's life here becomes a forceful witness, his suffering soul and his life ebbing away in God's service becomes a testimony of God. The priestly office is introduced alongside the prophetic office." 24

Through his openness to God about the severity and /or the cost of his calling, Jeremiah is able to provide his audience/readers with a window not only into the challenges of those who dare to come against the status quo, especially as it pertains to people's religious convictions, and thus the people's (including the prophet himself) long held beliefs and traditions about their faith in God and their valued institutions (cf. the Jerusalem temple), but also the situation of those who choose the route of self-denial. Those who choose the side of God, will of necessity come into conflict with humans who albeit religious (or so they thought), struggled to discern the will of God for the nation at that particular moment. The words of von Rad come to mind here, "This alignment with God, however, has a negative side: he who is totally turned toward God is consequently turned away from men ( $\mathrm{sic}$ ); it is just this inclination toward God that has isolated him from men (sic). The simplicity of this truth is striking; those who are turned toward God are removed from human community; and this position has nothing to do with pride vis-à-vis other men (sic)"'25 (1984:340)

In that particular space, present day readers of Jeremiah's laments are afforded an opportunity to also get a glimpse albeit small, of the nature of the God with whom Jeremiah could just be himself. Some of the confessions reveal this deity as a re-assuring one, a rebuking one, but also, more importantly for the present investigation, the deity who does not shy away from weeping. Just like Jeremiah, the weeping man, in the Jeremiah tradition, the deity, who is usually portrayed as a male, can "stoop" so low to do what is culturally designated as feminine. Yahweh can weep: "O that my head were waters, and my eyes a fountain of tears, that I might weep day and night for the slain of the daughter of my people!"'(Jer.8:23) ${ }^{26}$

\footnotetext{
24 Von Rad, The Confessions, 346.

25 Von Rad, The Confessions, 340.

26 O'Connor reasons, "The weeping God, with a head turned to waters, eyes become a fountain, desires to go on a crying bout for days and nights over Daughter Zion and
} 
The God whose wrath and fury against the sins and disobedience of God's people could be revealed in the message and body of Jeremiah, is at the same time, the God of empathy and compassion, ${ }^{27}$ one who also did not take pleasure at the judgement and punishment and calamity that were to befall God's beloved people. Says O'Connor, "Divine tears suggest a deity who vacates sovereignty and hierarchical transcendence, at least temporarily, and relates in vulnerability to the other, the daughter of my people." 28

Perhaps the prophet had taken the cue of his "loud" behaviour, his ability to express his tears effortlessly from the deity.

\section{E CONCLUSION}

The main question addressed by this essay is: Which reading may emerge if selected Sotho proverbs on specific masculinities are used as hermeneutical lenses through which to engage the confessions of Jeremiah? From the preceding discussion, it has hopefully been revealed that the humanity of male human beings can be allowed to be complete if they, like Jeremiah, choose to go against the patriarchal masculinist status quo with its contempt on male tears and emotions,

One would like to suggest that in a space where (male) worshippers meet the Sacred Other who is closely connected to them (cf. Yahweh in the case of Jeremiah), where men may dare to be their real selves, laying bare who they really are honestly and freely, as well as all what they feel before the Sacred Other, it seems to me that such a space enables the Sacred Other, to meet such men, right at their points of apparent "weakness." Such a close connection between Jeremiah and the deity seems to be endorsed by Walter Brueggemann when he argues, "Rather Jeremiah stays close to YHWH in his articulation of the pained, anguished, overwhelming despair. With good reason Jeremiah is known as the most troubled of the prophets. He aches and grieves, protests and rages.

her dead. So much sorrow overtakes God that an endless river of tears is required to express it." O'Connor, The Tears of God, 399.

27 Pamela J. Scalise sees such a creative tension between the element of divine "wrath" and divine grief. God mourned the suffering of Israelite individuals and families on account of the wickedness of their neighbours. The element of wrath though, is the other side of divine grief as divine justice demanded judgement on a corrupt society. In the process, the certainty of the judgement before it occurred were conveyed by divine mourning as well as the summons to mourn in Jeremiah's ministry. Pamela J Scalise. "The way of weeping: Reading the path of grief in Jeremiah," Word and World, 22/4, 2002: 415-422.

28 O' Connor, The Tears of God, 401. 
My point is simply that these "questionable" acts are Jeremiah's faithful way of staying close to YHWH."29

Such a space in which the expressions of one's true emotions, irrespective of how denigrated such emotions may be viewed or the gender of the person who expresses such emotions, may perhaps be the most appropriate space in which the message of the Sacred Other for the specific individual lamenter as well as his specific audience, could be appropriately delivered. Brueggemann could thus rightly argue, "Although the lamentations present deep problems for interpretation, there is little doubt that they evidence a theological confrontation of immense depth that scarred and engaged the prophetic personality and so gave profound force to his utterance- an utterance the prophet was compelled to offer against his own will." ${ }^{30}$ (italics: author's)

The fact that the confessions of Jeremiah were allowed to be retained "unfiltered," and thus freed to reflect the emotions of a real human being and not forced to don a "masculine" sheep-like garb, enables present day (male) readers to get a glimpse not only of the tears of a male human being, but even more importantly, of the tears of the Sacred Other. The latter fact, may enable present day readers of Jeremiah's confessions to have a more rounded version of the character of Yahweh, especially as the character in the Hebrew Bible. This is the God who can lavish harsh punishments (including deaths) on God's people but at the same time empathise to the extent of weeping on account of what is to befall the very same bunch of sinful and disobedient people. It appears that the harsh message of the impending judgement on the people of Judah could apparently be delivered as well as embodied by a man who dared to be human enough to complain, to cry and to weep.

A man who dared to argue like Temba: "To cry when hurt. That's what makes a man. Without tears, he is incomplete." 31

Such (male) humans who dare to minister in surprising and humiliating ways precisely on account of the very taxing prophetic word that they were entrusted with, may be pleasantly surprised by the therapy that accompanies loudness, tears and weeping irrespective of who uses such as the vehicles for the prophetic word.

Perhaps male worshippers and ministers of the word whose emotions have been contained for so long, such men who choose to get their cue from the

29 Walter Brueggemann, Like Fire in the bones: Listening to the Prophetic Word in Jeremiah, edited by Patrick D. Miller, (Minneapolis: Fortress, 2006), 184.

30 Walter Brueggemann, Old Testament Theology: The Theology of the Book of Jeremiah (Cambridge: Cambridge University Press, 2007), 34

31 Siphiwo Mahala. When a man cries (Pietermaritzburg: University of KwaZulu Natal Press, 2007), 250. 
life and ministry of Jeremiah as reflected in his confessions, may eventually obtain the freedom to be fully human and fully male. Perhaps the Honoree, Professor Willie Wessels, the man, the academic whose important Jeremiah scholarship is celebrated in this piece, as well as the minister of the Word, may be the right candidate to convey the contents of this piece to the male members of our communities. Perhaps the result especially for those who choose to listen, may be the production of the kind of masculinities which are affirming and liberating.

\section{BIBLIOGRAPHY}

Brueggemann, Walter. To pluck, to tear down: A Commentary on the Book of Jeremiah 1-25. Grand Rapids, MI: William B. Eerdmans; Edinburgh: The Handsel, 1988.

Brueggemann, Walter. Old Testament Theology: The Theology of the Book of Jeremiah. Cambridge: Cambridge University Press, 2007.

Like Fire in the bones: Listening to the Prophetic Word in Jeremiah. Edited by Patrick D. Miller, Minneapolis: Fortress, 2006. https://doi .org/10.2307/j.ctt22 $\underline{\mathrm{nmb} 7 \mathrm{r}}$

Baumgartner, Wakter. Translated by David E. Jeremiah's Poems of Lament. Orton Sheffield: Sheffield Academic, 1988.

Carroll, Robert P. Jeremiah, Volume 1. Sheffield: Sheffield Phoenix, 2006.

Carroll, R.P. Jeremiah. Sheffield: Sheffield Academic, 1989.

Chitando, Ezra. "Redemptive Masculinities, HIV, and Religion in Siphiwo Mahala's When a Man Cries" Pages 249-265 in Redemptive Masculinities: Men, HIV and Religion. Edited by Ezra Chitando and Sophie Chirongoma. Geneva: WCC.

Dube, Musa W. "Culture, Gender and HIV/AIDS: Understanding and Acting on the Issues "Pages 84-100 in HIV/AIDS and the Curriculum: Methods of Integrating HIV/AIDS in Theological Programmes. Edited by Musa W. Dube. Geneva: World Council of Churches. 2003.

Lundbom, Jack R. Jeremiah 1-20: A New Translation with Introduction and Commentary, $A B 21$ A. New York: Doubleday, 1999.

Mahala, Siphiwo. When a Man Cries. Pietermaritzburg: University of KwaZulu Natal, 2007.

Masenya (ngwana' Mphahlele), Madipoane and Ramatswana, Hulisani "Anything New under the Sun of Old Testament Scholarship? African Qoheleths' Review of OTE 1994-2010, OTE 25 (3): 598-637, 2012.

O'Connor, Kathleen M, "The Tears of God and Divine Character in Jeremiah 2-9." Pages 387-401 in Troubling Jeremiah. Edited by A.R. Pete Diamond, Kathleen M. O'Connor and Louis Stulman. Sheffield: Sheffield, 1999.

O'Connor, Kathleen, M. Jeremiah, Pain and Promise. Minneapolis: Fortress, 2012.

O'Connor, Kathleen, The Confessions of Jeremiah: Their Interpretation and Role in Chapters 1-25. Atlanta: Scholars, 1988.

O'Connor, Kathleen, “Jeremiah." Pages 267-277 in Women's Bible commentary, Twentieth Anniversary Edition. Edited by Carol A. Newsom, Sharon H. Ringe and Jacqueline E. Lapsley. Louisville: Westminster John Knox, 2012.

Polk, Timothy Polk. The Prophetic Persona: Jeremiah and the Language of Self. Sheffield: JSOT, 1984.

Rakoma, JRD. Marema-ka-dika tša Sesotho sa Leboa. Pretoria: Van Schaik, 1971. 
718 Masenya, “Jeremaih's Confessions," OTE 31/3 (2018): 705-718

Scalise J. Pamela. "The Way of Weeping: Reading the Path of Grief in Jeremiah," Word and World, 22/4, 2002: 415-422.

Von Rad, Gerhard, "The Confessions of Jeremiah." Pages 339-347 in A Prophet to the Nations: Essays in Jeremiah Studies. Edited by Leo G. Perdue and Brian W. Kovacs. Winona Lake, IN: Eisenbrauns, 1984.

Wessels, Wilhelm. "My Word is Like Fire": The Consuming Power of YHWH's Word, Old Testament Essays 24/2 (2011): 492-510.

White, R.E.O. The Indomitable Prophet: A Biographical Commentary on Jeremiah: The Man, the Time, the Book, the Tasks. Grand Rapids, MI: William B. Eerdmans, 1992.

Madipoane Masenya (Ngwan'a Mphahlele), Department of Biblical and Ancient Studies, University of South Africa, e-mail: masenmj@unisa.ac.za. ORCID ID: https://orcid.org/0000-0001-7373-2454. 